\title{
Histometric Parameters of Uterus and Vagina in Breeder Female Rabbits on the Day After Weaning According to the Ordinal Number of Parturitions
}

\author{
Parámetros Histométricos en Útero y Vagina de Conejas Reproductoras \\ en el día Posterior al Destete Según el Número Ordinal de Partos
}

\author{
José Alfonso Banda-Herrera*; Jesús Aragón Hernández**; Reyes López Ordaz ${ }^{* * *}$; \\ Jorge Hernández Espinosa* \& Mario Pérez-Martínez"
}

BANDA-HERRERA, J. A.; ARAGóN, H. J.; LÓPEZ, O. R.; HERNÁNDEZ, E. J. \& PÉREZ-MARTÍNEZ, M. Histometric parameters of uterus and vagina in breeder female rabbits on the day after weaning according to the ordinal number of parturition. Int. $\boldsymbol{J}$. Morphol., 32(2):732-737, 2014.

SUMMARY: The objective of this study was to establish in New Zealand female rabbits, the effect of ordinal number of parturitions on some histological parameters on the day after weaning. Tissue fragments of uterus and vagina were obtained from females of first, second and third parturitions and were processed imbedding them in paraffin in order to do histological cuts. In eight microscope fields captured by a camera connected to an optic microscope, the lumen and glandular endometrial epithelium height, as well as the thickness of vaginal and myometrium epithelium thickness were measured. From the results that were obtained it was concluded that there are significant differences $(p<0.05)$ in histological parameters evaluated in uterus and vagina between does of different parturitions, which indicates that the number of parturitions has an effect on histometric characteristics of genital tract organs in breeder female rabbits.

KEY WORDS: Histometry; Uterus; Vagina; Weaning; Rabbit Doe.

\section{INTRODUCTION}

Epithelia that cover tubular genital organs are constituted by closely related cells, which allow them to function as an efficient barrier between the luminal surface and the subjacent connective tissue. This topological and anatomical interaction is essential to the carrying out of tissue remodeling processes during different stages of the female reproductive cycle (Cooke et al., 1997).

Estrogens and progesterone participate in structural integrity maintenance of the oviduct, and the uterine and vaginal tissues. Both hormones regulate growth, proliferation and secretion function of reproductive tract epithelial cells. Likewise, the changes in concentration of these hormones during the estrus cycle induce hemodynamic changes in the vascular tissue that result in the increment of permeability of blood vessels and humid weight of the uterus (Kim et al., 2004; Vinci et al., 2010).
It is known that a predominantly estrogenic environment promotes epithelial and muscular tissue hyperplasia in the vagina and on the other hand when estrogen concentration is reduced, during old age, or when the individuals are ovariectomized, there is atrophy of the uterus and vagina walls (Boreham et al., 2002; Pessina et al., 2006). After the bunnies are weaned there are changes in the endocrine profile of the breeding doe amongst which ES concentration increase and prolactin concentration reduction are the most notable. This hormonal environment promotes follicular development in the ovary and in sexual receptivity (Ubilla et al., 2000).

In rabbit farms, weaning time for bunnies depends on the production system that is used and generally the systems are of the intensive type, with weaning carried out before 30 days of age, in semi-intensive systems between

\footnotetext{
* Departamento de Morfología, Facultad de Medicina Veterinaria y Zootecnia. Universidad Nacional Autónoma de México. Ciudad de México, México

** Facultad de Agrobiología. Universidad Autónoma de Tlaxcala, Xalpatlahuaya, Huamantla, Tlaxcala, México.

*** Departamento de Producción Agrícola y Animal, Universidad Autónoma Metropolitana Unidad Xochimilco. Ciudad de México, México
} 
35 and 40 days of age and in extensive systems between 7 and almost 8 weeks of age (Jandete et al., 2010).

Total lactation time has been subdivided into two stages. In the first stage the bunnies only ingest milk and during the second stage they consume milk together with small portions of solid food. Weaning time of small rabbits is a process whereby the offspring slowly change from a totally milk-based diet to a semisolid diet and finally when the individual acquires the capacity to ingest solid food it does so. As the bunnies begin the consumption of solid food, the energy load of the mother starts to fall, which is a sign to the neural and endocrine mechanisms that regulate lactation which in turn influences ovarian function and structural changes in reproductive organs.

It is necessary that current rabbit production schemes be evaluated in order to determine their impact on reproductive females' physiology. One of these topics to be reviewed is the changes that occur in reproductive organs of the female rabbit at different times after weaning in relation to the ordinal number of parturitions. Due to the above, the objective of this study was to establish in New Zealand female rabbits on the day after weaning, the effect of ordinal number of parturitions on the histological parameters: lumen and glandular endometrial epithelium height and myometrium and vaginal epithelium thickness in the cranial and caudal portions.

\section{MATERIAL AND METHOD}

Twelve adult non-pregnant, lactating, clinically healthy, New Zealand breed does obtained from a commercial farm located in Tlaxcala, Mexico were included in this study, They were kept under a controlled light-darkness cycle (16 h light: $8 \mathrm{~h}$ darkness) in individual metal cages. The does had free access to a commercial pellet diet (Purina $\left.{ }^{\circledR}\right)(18 \%$ crude protein and $15.5 \%$ crude fiber) and water ad libitum. Efforts were made to minimize both animal suffering and the number of animals used. A total of 12 rabbit does in their first, second or third parturition with a live weight range from 3 to $3.5 \mathrm{Kg}$ were used (Three groups, $n=4$ per group). None of the lactating females used in this study was mated. Weaning of the litter was carried out on day 30 post-parturition. As reference a group of prepubescent rabbits of the same breed were included ( 8 weeks of age) $(n=3)$.

Females were euthanized 24-hours after weaning by neck-breaking desensitization and immediately cutting the jugular vein. The study carried out followed Mexican
Law for the Protection of wild and domestic animals, and the Mexican Official Standard NOM-033-ZOO-1995. After euthanasia of the rabbits an incision was made at the abdominal midline to separate uterus, vagina and ovaries. Fragments were obtained from the middle third of the uterus and vagina and the longitudinal middle of the ovaries and immediately introduced into a $10 \%$ buffered formalin solution to be set for 72 hours.

Tissues were processed by paraffin inclusion technique and cut by microtome (Leica RM2125RT®); from the blocks five $6 \mu \mathrm{m}$ thick slices were obtained and stained by Gomori Trichrome stain. This stain facilitates the identification of the different tissues when carrying out measurements. From each cut eight microscope fields were selected for histometric analysis (Wei et al., 2011). Measurements were carried out with the 40X objective lens of an optical microscope (Motic BA310®) connected to a digital microscopy camera (Moticam $2300 ®$ ) and an image analysis software (Motic Images Plus $®$, version 2.0).

In each microscope field the height of the luminal and glandular endometrium epithelium and the thickness of the myometrium and vaginalepithelium at the cranial and caudal portion were measured. Measurement of the glandular epithelium was carried out at four different sites of the gland.

Primary and secondary follicles existing in the cortical zone were counted in the histological cuts of the ovaries of the first, second and third parturition and the prepubescent groups with the objective 40x and with the objective 10x tertiary type follicles in the cortical and medullar zones. Groups were compared with the data obtained from the measurements by the Kruskal Wallis non-parametric test (program SAS, version 9.0).

\section{RESULTS}

Results obtained from histometry of the luminal and glandular endometrial height, thickness of myometrium and vaginal epithelium at the cranial and caudal portions are shown by groups under study in Table I and Figures 1 to 5 , where significant differences are indicated between groups $(\mathrm{p}<0.05)$.

Endometrial epithelium height was significantly less in the second and third parturition groups as compared with the first parturition group $(\mathrm{p}<0.05)$. On the other hand, the endometrial epithelium height of the group of prepubescent females was less as compared to the first, second and third 
parturition groups $(\mathrm{p}<0.05)$. Endometrial glands were not found to be present in prepubescent females (Fig. $6 \mathrm{~A}$ and B). In relation to the height of the glandular epithelium, it was less in height in the third parturition group when compared to the first and second parturition groups $(\mathrm{p}<0.05)$. Myometrium thickness was less in the prepubescent and first parturition groups as compared to the second and third parturition groups $(\mathrm{p}<0.05)$. Epithelium thickness of the anterior and caudal vagina was smaller in the prepubescent and first parturition groups as compared to the second and third parturition groups $(\mathrm{p}<0.05)$.

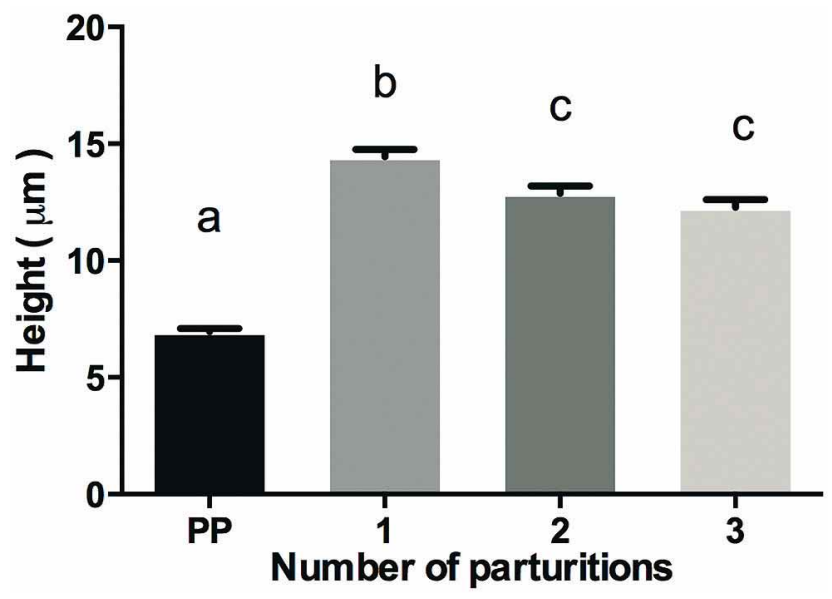

Fig. 1. Endometrial luminal epithelium height of prepubescent and adult females of third, second and third parturitions. Values are expressed as an average $\pm \mathrm{SE}$. $\mathrm{PP}=$ prepubescent females.

*Different letters indicate significant difference between groups $(\mathrm{p}<0,05)$.

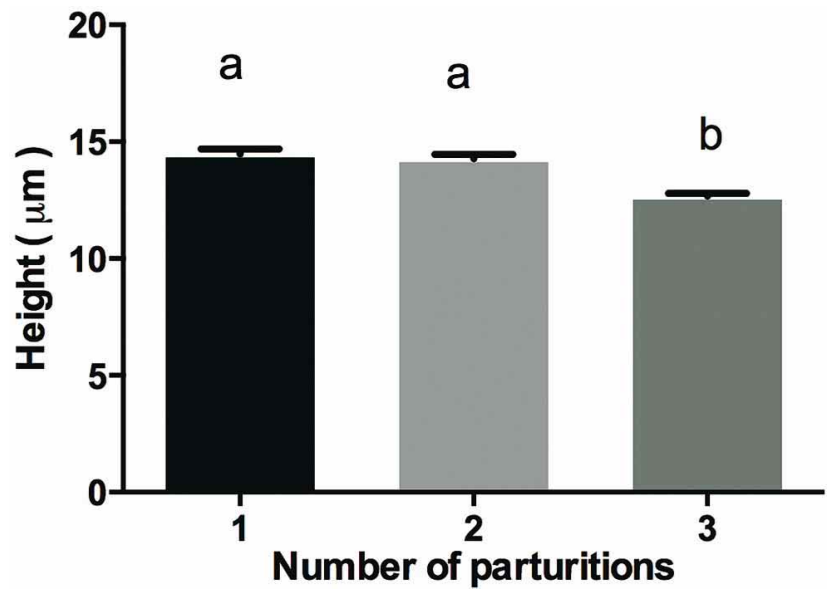

Fig. 2. Height of endometrial gland epithelium of prepubescent and adult females of first, second and third parturitions. The values are expressed as an average $\pm \mathrm{SE}$. $\mathrm{PP}=$ prepubescent females.

* Different letters indicate significant difference between groups $(\mathrm{p}<0,05)$.

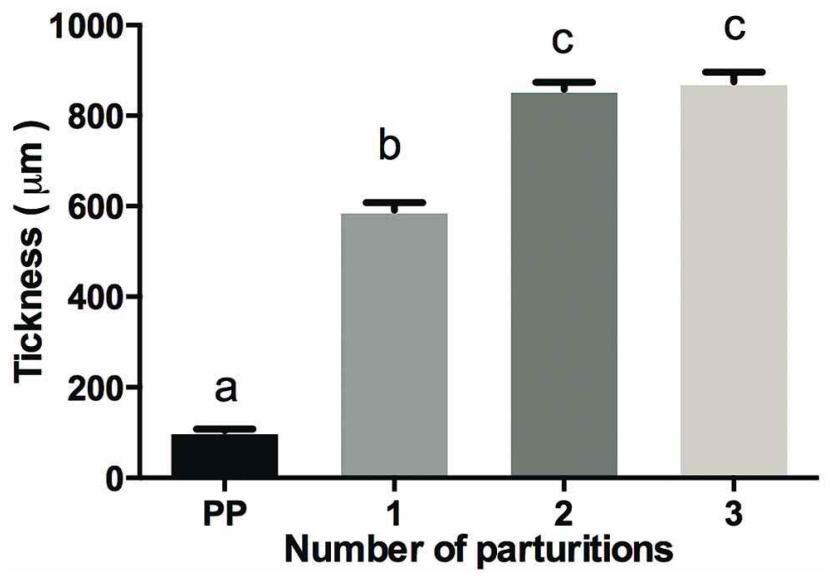

Fig. 3. Thickness of the muscular layer in prepubescent and adult females of first, second and third parturition. Values are expressed as an average $\pm \mathrm{SE}$. $\mathrm{PP}=$ prepubescent females.

* Different letters indicate significant difference between groups $(\mathrm{p}<0,05)$.

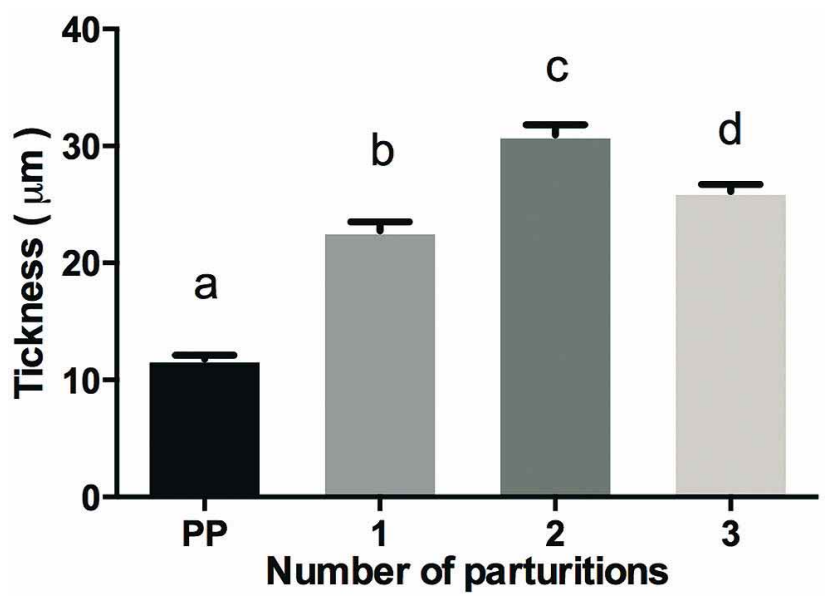

Fig. 4. Thickness of the vagina epithelial lamina in its cranial portion in prepubescent and adult females of first, second, and third parturition. Values are expressed as an average $\pm \mathrm{SE}$. PP= prepubescent females.

* Different letters indicate significant difference between groups $(\mathrm{p}<0,05)$.

Table I. Total count number of ovarian follicles in prepubescent and adult females of first, second and third parturition.

\begin{tabular}{lccc}
\hline & \multicolumn{3}{c}{ Type of follicles } \\
\cline { 2 - 4 } Group* & Primary & Secondary & Tertiary \\
\hline Prepubescent & 28 & 16 & 0 \\
First parturition & 30 & 14 & 3 \\
Second parturition & 12 & 9 & 2 \\
Third parturition & 12 & 9 & 3 \\
\hline
\end{tabular}

*Data shown as total count of follicles present in each studied group. 


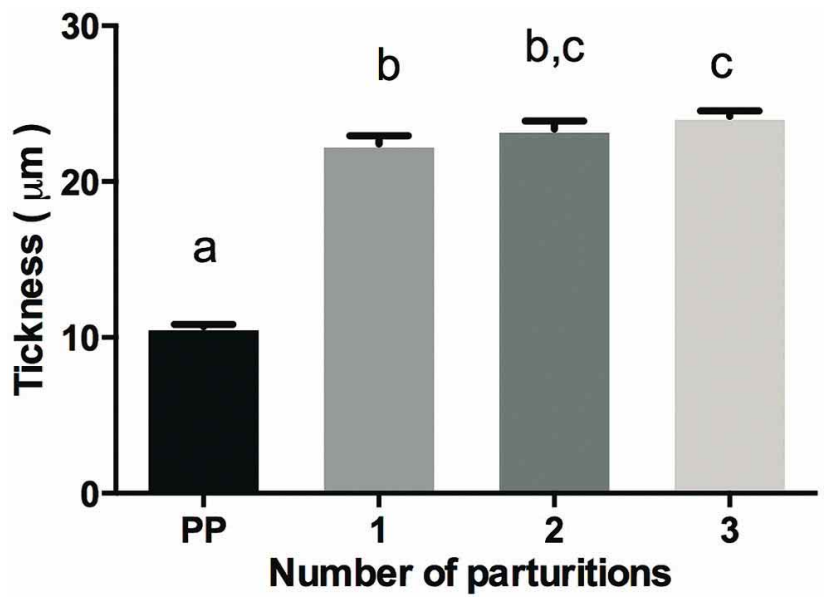

Fig. 5. Thickness of the vagina epithelial lamina in its caudal portion in prepubescent and adult females of first, second, and third parturitions. Values are expressed as an average $\pm \mathrm{SE} . \mathrm{PP}=$ prepubescent females.

* Different letters indicate significant difference between groups $(\mathrm{p}<0,05)$.

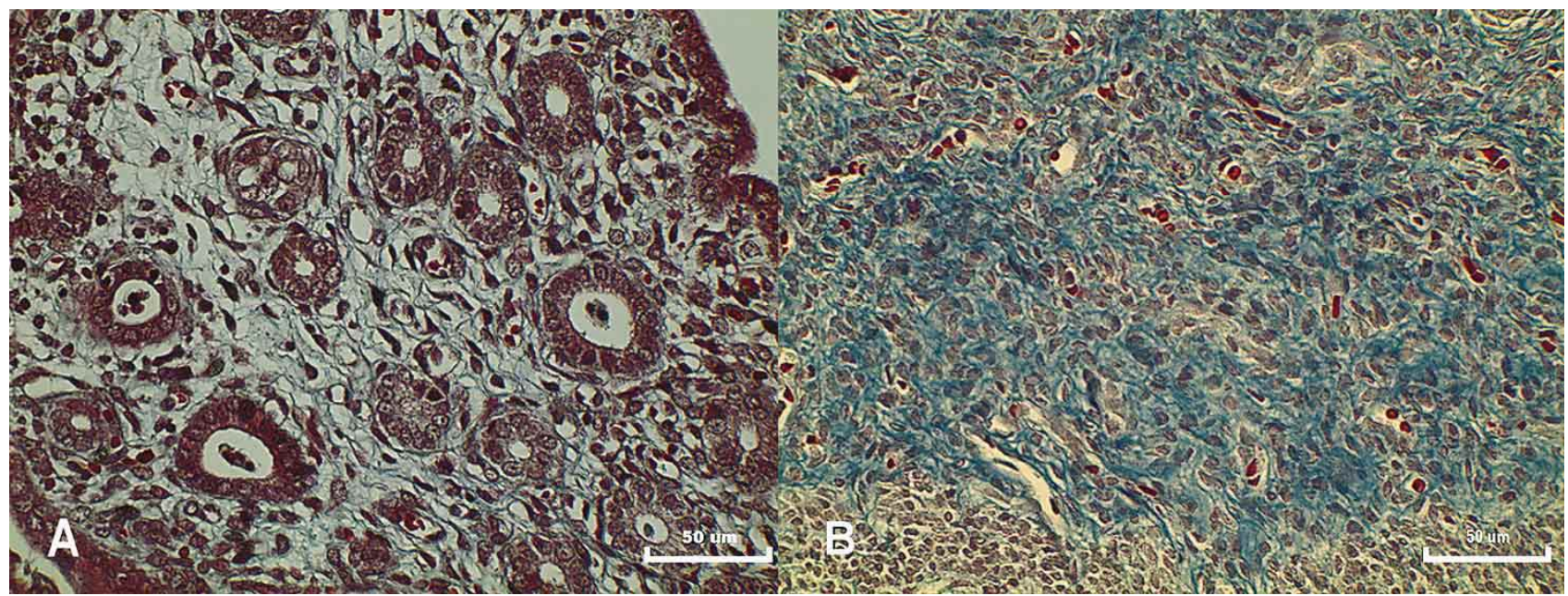

Fig. 6. A. Presence of endometrial glands in adult rabbit uterus of first parturition. Gomori Trichrome stain (400X). B. Lack of endometrial glands in prepubescent rabbit uterus. Gomori Trichrome stain $(400 \mathrm{X})$. Bar $=50 \mathrm{~mm}$.

\section{DISCUSSION}

Ovarian activity was evidenced by consistently observing primary, secondary and tertiary follicles in ovarian tissue cuts of first, second and third parturition females. In a previous study in does, it was reported that after weaning of a litter there is an increase in circulating estrogens, a reduction in prolactin concentration and ovarian follicles development (Ubilla et al.). Likewise, it is well known that during the lactating period, ovarian follicle population is reduced (CreenwaId \& Terranova, 1988). In relation to the reduction of endometrial luminal epithelium cells height in females of the second and third parturition in relation to those of the first parturition, it has been reported that in the albino rabbit uterine involution in postpartum females is completed until the 11th day postpartum and histologically this change is accompanied by a reduction of endometrial and myometrial tissue, together with scarce development of endometrial glands (Foxcroft \& Hasnain, 1973). In our study we did not find significant differences in endometrial glandular epithelium height in females of first and second parturition, nevertheless third parturition females showed lesser height. It is noteworthy that we did not observe the presence of endometrial glands nor tertiary follicles in the eight weeks prepubescent group of females which suggests that the capacity for estrogen synthesis by ovarian follicles of females in this group is still not sufficient to activate mechanisms to regulate organization and development of endometrial glands. As it is known, when the uterus is under estrogenic environments, growth factor synthesis is induced promoting local vascular development which in turn favors an increase in oxygen and nutrient provision to the 
endometrium, and this causes cellular proliferation. Likewise, it is interesting that in prepubescent females the endometrium did not show lymphocyte presence, which is present in adult females that have given birth. It has been reported that lymphocyte flooding of the endometrium at intraepithelial and interstitial levels is a process influenced by estrogens (Pérez-Martinez et al., 2002; Fahey et al., 2006; Anzaldúa Arce et al., 2008). Leukocytes have a key role in the "cleaning" processes of the reproductive tract tissues, which can be corroborated when the uterine mucosa is infiltrated by leukocytes few hours after coitus (Bedford, 1965). Nevertheless, this finding cannot be interpreted at this time and this should be analyzed in further studies of migratory dynamics of leukocytes going towards the uterus after weaning and their implication on uterine immunity.

Females of first, second and third parturition consistently had well defined muscular layers. Differences found in myometrium layer thicknesses between females of the first parturition group, with the second and third parturition groups, indicate that smooth muscles respond to the hormonal environment present during the hours after the bunnies are weaned and that their thickness is modified with the parturition ordinal number. It is known that the older the female and higher the parturition ordinal number the capacity of tissues to recover their form and size is reduced.

It has been observed in animal models that elasticity and tonicity of uterine tissues are gradually reduced as the female ages and this change is directly related with the increase of collagen protein content in uterine tissue; likewise, it is know that ES stimulate collagen deposits throughout the reproductive life of the female (Mulholland
\& Jones, 1993; Kong et al., 2012).

Significant differences were found in vaginal epithelium between females of different parturition ordinal number and that was similar to what was observed in luminal and glandular endometrial epithelium. Vaginal epithelium is characterized by its great sensitivity to estrogen and progesterone concentration changes during the different reproductive stages. It is well known that in domestic mammals vaginal epithelium cells have a variation in the pattern of exfoliated cells which is indicative of the reproductive stage of the female (Pérez-Martínez et al., 1999). When comparing adult female groups it was found that epithelial lamina thickness of the vagina in the caudal and cranial sections increases with the parturition ordinal number.

In conclusion, our findings indicate that histometric characteristics of uterus and vagina of New Zealand does vary in relation to the parturition ordinal number, which can influence the level of follicular activity post-weaning. Likewise, in future studies other aspects should be taken into account such as feed type, body condition, and reproductive handling practices of the farm.

\section{ACKNOWLEDGMENTS}

This study was partially financed by DGAPAUNAM, project PAPIME (PE201711). We thank Technician Francisco Lopez, assigned to the Morphology Department of FMVZ-UNAM, for his aid in tissue processing.

BANDA-HERRERA, J. A.; ARAgóN, H. J.; LÓPEZ, O. R.; HERNÁNDEZ, E. J. \& PÉREZ-MARTÍNEZ, M. Parámetros histométricos en útero y vagina de conejas reproductoras en el día posterior al destete según el número ordinal de partos. Int. J. Morphol., 32(2):732-737, 2014.

RESUMEN: El objetivo del presente estudio fue determinar en conejas Nueva Zelanda el efecto del número ordinal de partos sobre algunos parámetros histológicos, en el día posterior al destete. A partir de hembras de primero, segundo y tercer parto se obtuvieron fragmentos de tejido uterino y vaginal los que se procesaron mediante la técnica de inclusión en parafina para efectuar cortes histológicos. En ocho campos microscópicos capturados con una cámara conectada a un microscopio óptico se midió la altura del epitelio luminal y glandular del endometrio; el grosor del epitelio de la vagina y del miometrio. A partir de los resultados obtenidos se concluye que existen diferencias significativas $(\mathrm{p}<0,05)$ en los parámetros histológicos evaluados en útero y vagina entre las conejas de distintos partos, lo que indica que el número de partos tiene un efecto sobre las características histométricas de los órganos del tracto genital de la coneja.

PALABRAS CLAVE: Histometría; Útero; Vagina; Destete; Coneja

\section{REFERENCES}

Anzaldúa Arce, S. R.; Villaseñor Gaona, H. \& Pérez-Martínez, M. Variación en la distribución de linfocitos epiteliales e intersticiales en tubas uterinas de la coneja al inicio de la gestación. Tec. Pecu. Méx., 46(3):333-44, 2008. 
Bedford, J. M. Effect of environment on phagocytosis of rabbit spermatozoa. J. Reprod. Fertil., 9:249-56, 1965.

Boreham, M. K.; Wai, C. Y.; Miller, R. T.; Schaffer, J. I. \& Word, R. A. Morphometric analysis of smooth muscle in the anterior vaginal wall of women with pelvic organ prolapse. Am. $J$. Obstet. Gynecol., 187(1):56-63, 2002.

Cooke, P. S.; Buchanan, D. L.; Young, P.; Setiawan, T.; Brody, J.; Korach, K. S.; Taylor, J.; Lubahn, D. B. \& Cunha, G. R. Stromal estrogen receptors mediate mitogenic effects of estradiol on uterine epithelium. Proc. Natl. Acad.Sci. U.S.A., 94(12):653540, 1997.

Greenwald, G. S. \& Terranova, P. F. Follicular selection and its control. In: Knobil, E. \& Neill, J. D. (Eds.). The Physiology of Reproduction. New York, Raven Press, 1988. pp.387-445.

Fahey, J. V.; Schaefer, T. M \& Wira, C. R. Sex hormone modulation of human uterine epithelial cell immune responses. Integr. Comp. Biol., 46(6):1082-7, 2006.

Foxcroft, G. R \& Hasnain, H. Effects of suckling and time to mating after purturition on reproduction in the domestic rabbit. $J$. Reprod. Fertil., 33(3):367-77, 1973.

Jandete H.; Martínez M \& Gálvez A. Introducción a la Zootecnia. Trujillo, M. E. (Ed.). México D. F. Universidad Nacional Autónoma de México, Facultad de Medicina Veterinaria y Zootecnia, 2010.

Kim, N. N.; Min, K.; Pessina, M. A.; Munarriz, R.; Goldstein, I. \& Traish, A. M. Effects of ovariectomy and steroid hormones on vaginal smooth muscle contractility. Int. J. Impot. Res., 16(1):43-50, 2004.

Kong, S.; Zhang, S.; Chen, Y.; Wang, W.; Wang, B.; Chen, Q.; Duan, E. \& Wang, H. Determinants of uterine aging: lessons from rodent models. Sci. China Life Sci., 55(8):687-93, 2012.

Mulholland, J. \& Jones, C. J. Characteristics of uterine aging. Microsc. Res. Tech., 25(2):148-68, 1993.

Pérez-Martínez, M.; Mendoza, G. M.\& Romano, M. C. Exfoliative vaginal cytology and plasma levels of estrone and estradiol$17 \mathrm{~b}$ in young and adult goats. Small Rumin. Res., 33(2):153-8, 1999.

Perez-Martinez, M.; Luna, J.; Mena, R. \& Romano, M. C. Lymphocytes and $\mathrm{T}$ lymphocyte subsets are regionally distributed in the female goat reproductive tract: influence of the stage of the oestrous cycle. Res. Vet. Sci., 72(2):115-21, 2002.

Pessina, M. A.; Hoyt, R. F. Jr.; Goldstein, I. \& Traish, A. M. Differential effects of estradiol, progesterone, and testosterone on vaginal structural integrity. Endocrinology, 147(1):61-9, 2006.
Ubilla, E.; Rebollar, P. G.; Pazo, D.; Esquifino, A. \& Alvariño, J. M. R. Effects of doe-litter separation on endocrinological and productivity variables in lactating rabbits. Livest. Prod. Sci., 67(1-2):67-74, 2000.

Vinci, A.; Bacci, B.; Benazzi, C.; Caldin, M. \& Sarli, G. Progesterone receptor expression and proliferative activity in uterine tumours of pet rabbits. J. Comp. Path., 142(4):323-7, 2010.

Wei, S.; Bai, J.; Gong, Z.; Ma, W. \& Wei, M. GnRH agonist active immunization influences ovarian development and GnRH receptor mRNA expression levels of pituitary in Japanese white rabbits (Oryctolagus cuniculus). Livest. Sci., 139(3):222-9, 2011.

\author{
Correspondence to: \\ Dr. Mario Pérez Martínez \\ Profesor Titular \\ Departamento de Morfología \\ Laboratorio de Biología Tisular de la Reproducción \\ Facultad de Medicina Veterinaria y Zootecnia \\ Universidad Nacional Autónoma de México \\ Avenida Universidad 3000 \\ México, D.F. 04510. \\ MÉXICO
}

Email address: perezmtzmario@yahoo.com.mx

Received: 07-10-2013

Accepted: 01-02-2014 